\title{
Evaluation of physicochemical properties and viability of starter culture of liquid cheese whey-based frozen yogurts supplemented with inulin
}

\author{
Viviane Michele dos Santos ${ }^{*}$ (iD) Gerlane Souza de Lima ${ }^{1}$ (D) \\ Viviane Lansky Xavier de Souza Leão ${ }^{2}$ Karina Correia da Silveira $^{2}$ (D) \\ Tânia Lúcia Montenegro Stamford ${ }^{1}$
}

${ }^{1}$ Programa de Pós-graduação em Nutrição, Departamento de Nutrição, Universidade Federal de Pernambuco (UFPE), 50731-250, Recife, PE, Brasil. E-mail: vivisan6@yahoo.com.br. *Corresponding author.

${ }^{2}$ Departamento de Nutrição, Universidade Federal de Pernambuco (UFPE), Recife, PE, Brasil.

ABSTRACT: The study aimed to analyze the physicochemical properties and starter culture viability of frozen yogurts produced with liquid cheese whey (LCW) and inulin at different proportions (F0: $66 \%$ LCW and $0 \%$ inulin; F1: $65 \%$ LCW and $1 \%$ inulin; F2: $64 \%$ LCW and 2\% inulin; F3: $62 \% \mathrm{LCW}$ and 4\% inulin). Results demonstrated that the frozen yogurt F3 presented higher total solids and carbohydrates levels. $L C W$ and inulin contributed to the overrun increase (11.8-18.2\%) but did not interfere significantly in the retardation of the melting rate and range in the samples' hardness. Over the storage time, formulation F3 showed lower pH and higher titratable acidity. However, from the sixtieth day of storage, the formulations of frozen yogurts varied in the $\mathrm{pH}$ and titratable acidity profile associated with the decline in the viability of starter cultures. Even so, the inulin supplementation positively affected the strains'viability during storage. Based on our data, the formulation F3 presented better nutritional value, physicochemical characteristics, and stability over the storage period. Key words: whey proteins, prebiotics, fiber, Streptococcus thermophilus, Lactobacillus delbrueckii.

Avaliação de propriedades físico-químicas e viabilidade de culturas starters de frozen yogurts à base de soro líquido de queijo suplementados com inulina

RESUMO: $O$ estudo teve como objetivo analisar as propriedades físico-químicas e a viabilidade das culturas starters de frozen yogurts produzidos com soro líquido de queijo (SLQ) e inulina em diferentes proporções (F0: 66\% SLQ e 0\% inulina; F1: 65\% SLQ e 1\% inulina; F2: $64 \%$ SLQ e 2\% inulina; F3: $62 \%$ SLQ e 4\% inulina). Os resultados demonstraram que o frozen yogurt F3 apresentou maiores teores de sólidos totais e carboidratos. SLQ e inulina contribuíram para o aumento do overrun (11.8-18.2\%), mas não interferiram significativamente no retardo da taxa de derretimento e na variação da dureza das amostras. Ao longo do tempo de armazenamento, a formulação F3 apresentou menor pH e maior acidez titulável. Porém, a partir do sexagésimo dia de armazenamento, as formulações de frozen yogurts variaram o perfil de pH e acidez titulável associado ao declínio da viabilidade das culturas starter. Mesmo assim, a suplementação de inulina afetou positivamente a viabilidade das cepas durante o armazenamento. Com base em nossos dados, a formulação F3 apresentou melhor valor nutricional, características físico-químicas e estabilidade ao longo do periodo de armazenamento.

Palavras-chave: proteinas do soro, prebioticos, fibra, Streptococcus thermophilus, Lactobacillus delbrueckii.

\section{INTRODUCTION}

Liquid cheese whey (LCW) is a byproduct from the cheese industry obtained of the enzymatic or acid coagulation process of milk. In terms of nutritional composition, it is a raw material containing lactose, proteins, minerals, and reduced lipid content (GUIMARÃES et al., 2019; MANN et al., 2019). The high content of nutrients, the good buffering capacity are factors that make LCW an efficient matrix for fermentative processes, especially in fermented foods (MITUNIEWICZ-MAŁEK et al., 2019). Yet, proteins, mainly $\beta$-lactoglobulin, $\alpha$-lactalbumin, and other whey constituents, are known for their technological properties, such as emulsification, gelation, foaming, as well as acting as a fat substitute (LAZIDIS et al., 2016; LAJNAF et al., 2018). Additionally, LCW represents a low-cost raw material. Thus, the use of LCW in the development of new products becomes a sustainable alternative for the reduction of environmental pollution and may even beneficiate the field of functional foods (GUIMARÃES et al., 2019; MENESES et al., 2020).

Prebiotics are non-viable food ingredients that selectively stimulate the hosts' microorganisms conferringhealth benefits according to the International 
Scientific Association for Probiotics and Prebiotics (ISAPP) (GIBSON et al., 2017), being the inulin one of the most popular prebiotics (GUIMARÃES et al., 2019). Its regular administration modulates the intestinal composition, with the predominance of Lactobacillus and/or Bifidobacterium spp in the colon. The growth and bacterial activity of these groups of microorganisms promote intestinal health improvement (GIBSON et al., 2017; MOGHADAM et al., 2019). Inulin presents solubility in water, does not interfere with the color and odor of foods, functions as a substitute for fat and sugar, in addition to improving the rheological properties of dairy products (MOGHADAM et al., 2019), such as yogurts (BOENI \& POURAHMAD, 2012), dairy beverages (GUIMARÃES et al., 2019), besides traditional ice creams and frozen yogurts (REZAEI et al., 2014; AKBARI et al., 2016), respectively.

The Brazilian legislation determines regulatory standards for frozen yogurt, and it may be defined as food obtained primarily from milk fermented by Streptococcus thermophilus and Lactobacillus bulgaricus or from yogurt with or without the addition of other food substances, and subsequently stirred and frozen (BRASIL, 2000). Frozen yogurts combine good sensory characteristics and nutritional advantages, like low-fat content and the presence of viable bacteria of fermented dairy products, with the physical properties of ice cream, as such overrun and texture (ISIK et al., 2011; MUZAMMIL et al., 2017). Thus, frozen yogurt proves to be a nutritionally viable option compared to conventional ice cream (SKRYPLONEK et al. 2019).

To the best of our knowledge, there are no studies regarding the effects of milk partial substitution by LCW associated with inulin in the production of frozen yogurt. Therefore, this work focuses on the physicochemical properties and starter cultures viability of frozen yogurts elaborated with LCW supplemented with inulin.

\section{MATERIALS AND METHODS}

\section{Frozen yogurt production}

The frozen yogurts were produced with whole milk powder (Itambé, Belo Horizonte, Brazil), sugar (Petribu, Lagoa de Itaenga, Brazil), fermented milk prepared from one liter of milk and spray dry starter culture containing L. bulgaricus and S. thermophilus (Nova Fórmula Laboratory, Recife, Brazil), emulsifier (Selecta, Jaraguá do Sul, Brazil), stabilizer (Selecta, Jaraguá do Sul, Brazil), inulin (degree of polymerization $\geq 10$, Orafti ${ }^{\circledR} \mathrm{GR}-$ Beneo-Orafti S.A., Belgium), liquid cheese whey obtained from acid-precipitated cheese type “coalho" (Dairy Industry FACO Ltda, Ribeirão, Brazil). Inulin concentrations followed a study by AKBARI et al. (2016), with adaptations. The composition of the frozen yogurts formulations are presented in the table 1 .

Initially, fermented milk was prepared from one liter of milk (whole milk powder reconstituted to $13 \%$ with sterile distilled water) and one gram of spray dry starter culture (containing $1.0 \times 10^{12} \mathrm{CFU}$ $\mathrm{g}^{-1}$ of each microorganism). There was no adjustment in the solids content. After this process, the mixture was incubated in an oven at $42{ }^{\circ} \mathrm{C}$ for $4 \mathrm{~h}$ (SOARES et al., 2011). For each formulation, a liter of yogurt mix was prepared. All ingredients, but the emulsifier, were weighed and mixed proportionally to the LCW, previously pasteurized at $90^{\circ} \mathrm{C}$ for $5 \mathrm{~min}$ in a water bath. To this mixture was added the fermented milk (90:10), homogenized and incubated at $42{ }^{\circ} \mathrm{C}$ for $6 \mathrm{~h}$. After fermentation, the yogurt mix was cooled for $12 \mathrm{~h}$ in

Table 1 - Frozen yogurt formulations with different concentrations of LCW and inulin.

\begin{tabular}{|c|c|c|c|c|}
\hline \multirow[t]{2}{*}{ Ingredients } & \multicolumn{4}{|c|}{------------------------------------------Formulations (\%)-------------------------------------- } \\
\hline & F0 & F1 & F2 & F3 \\
\hline Whole milk powder & 12.0 & 12.0 & 12.0 & 12.0 \\
\hline Sugar & 10.0 & 10.0 & 10.0 & 10.0 \\
\hline Fermented milk & 10.0 & 10.0 & 10.0 & 10.0 \\
\hline Emulsifier & 1.0 & 1.0 & 1.0 & 1.0 \\
\hline Stabilizer & 1.0 & 1.0 & 1.0 & 1.0 \\
\hline Inulin & 0.0 & 1.0 & 2.0 & 4.0 \\
\hline Liquid cheese whey & 66.0 & 65.0 & 64.0 & 62.0 \\
\hline Total & 100 & 100 & 100 & 100 \\
\hline
\end{tabular}

Ciência Rural, v.51, n.12, 2021. 
a refrigerator. Then, the yogurt mix was aerated and frozen in ICE - 21 Series Ice Cream Maker (capacity $1.5 \mathrm{~L}$, Cuisinart ${ }^{\circledR}$, USA) with emulsifier for $15 \mathrm{~min}$. After this process, $60 \mathrm{~g}$ of the frozen yogurts were packed in plastic cups and kept frozen at $-18^{\circ} \mathrm{C}$.

\section{Physical and physicochemical properties}

The protein, lipid, carbohydrate, and total solids contents, as well as $\mathrm{pH}$, acidity expressed as lactic acid, of the formulations were measured according to the specifications of the Association of Official Analytical Chemistry (AOAC, 2016). During the frozen yogurt storage, $\mathrm{pH}$ and titratable acidity were the parameters evaluated at 1, 30, 60, 90 , and 120 days. The percentage of overrun was calculated according to the following equation (Equation 1) (AKIN et al., 2007).

Overrun $(\%)=\frac{[\text { (mass of yogurt mix })-(\text { mass of frozen yogurt })] \times 100}{\text { mass of frozen yogurt }}$

\section{Melting rate}

The melting rate test followed MUSE \& HARTEL(2004) method, with small modifications. Sixty grams of the frozen yogurt samples were accommodated on a wire mesh screen $(2 \mathrm{~mm})$ on a beaker at a controlled temperature of $24^{\circ} \mathrm{C}$, and the drained volume recording lasted for over $60 \mathrm{~min}$. Results were expressed as time (min) against drained volume (\%).

\section{Texture analysis}

The texture of the frozen yogurts was measured after one week of storage in a texture analyzer CT3 (Brookfield Engineering Laboratories Inc., Middleboro, MA, USA) coupled to a cylindrical probe with a diameter of $38.1 \mathrm{~mm}$. The conditions for analysis were: penetration depth, $10 \mathrm{~mm}$; force, $6 \mathrm{~g}$; probe speed during penetration, $1 \mathrm{~mm} \cdot \mathrm{s}^{-1}$; probe speed before and after penetration, $2 \mathrm{~mm} \cdot \mathrm{s}^{-1}$. The assays were performed in quadruplicate. The hardness was measured as the peak pressure force $\left(\mathrm{g}^{-1}\right)$ during sample penetration (AKBARI et al., 2016).

\section{Enumeration of starter culture microorganisms}

The counts of starter cultures (L. bulgaricus and $S$. thermophilus) were performed in triplicate at $1,30,60,90$ and 120 days of storage at $-18{ }^{\circ} \mathrm{C}$. For this purpose, $25 \mathrm{~g}$ of sample was mixed with 225 $\mathrm{mL}$ of sterile buffered peptone water (Acumedia Manufacturers, Inc., USA) at a concentration of 20 g. $\mathrm{L}^{-1}$, followed by serial dilutions and determination of viable cell numbers achieved by the pour plate technique. The count of $L$. bulgaricus was performed on MRS agar (Merck, Germany) adjusted to $\mathrm{pH} 5.4$ \pm 1 with glacial acetic acid and anaerobic incubation at $37{ }^{\circ} \mathrm{C}$ for $72 \mathrm{~h}$ (IDF, 2003). The count of $S$. thermophilus utilized Streptococcus thermophilus agar in aerobic incubation at $37^{\circ} \mathrm{C}$ for 24 hours $\mathrm{h}$ (DAVE \& SHAH, 1996). The results were expressed as $\log$ CFU.g ${ }^{-1}$ of the sample.

\section{Statistical analysis}

The analyses were performed in triplicate. From the data obtained, the mean and the standard deviation of the analysis were calculated. The differences between the groups were determined by analysis of variance (ANOVA), followed by the Tukey test, at the level of $5 \%$ of significance, performed through the software GraphPad Prism version 6.01 (GRAPHPAD SOFTWARE, INC., LA JOLLA, CA, USA).

\section{RESULTS AND DISCUSSION}

\section{Physical and physicochemical properties}

Table 2 shows the results of the nutritional composition of frozen yogurts samples, which were in the following range $(\mathrm{g} / 100 \mathrm{~g})$ : protein $(3.77-4.40)$, lipids (3.10-4.57), and carbohydrates (18.16-22.32).

All formulations evaluated met the general requirements established by Resolution RDC 266/2005, which approves the technical regulation for fixing identity and quality of edible ice cream and, prepared for edible ice cream, powders for preparation and bases for edible ice cream (BRASIL, 2005). The protein and fat content of the formulations met the specifications, presenting higher values than the recommended minimum parameters $(2.5 \%$ and $3 \%$ ), respectively.

The results showed that the levels of carbohydrates and total solids were significantly affected by the different concentrations of inulin $(\mathrm{P}<0.05)$ (Table 2). Chemically, inulin is a linear fructan formed of fructose chains connected by $\beta-(2-1)$ bonds, and glucose unit linked by $\alpha-(2-1)$ bonds (MOGHADAM et al., 2019). Thus, because it is a polysaccharide, this characteristic of the ingredient increased significantly in the level of carbohydrates and the total solids in the formulations. The total solids content represents all the ingredients that make up the product, except for water. Similarly, TIWARI et al. (2015) observed a significant variation in carbohydrate content, and MUZAMMIL et al. (2017) showed that the total solids were positively affected by inulin supplementation in frozen yogurts. 
Table 2 - Physical and physicochemical parameters of frozen yogurt formulations.

\begin{tabular}{|c|c|c|c|c|}
\hline Parameters & F0 & $\mathrm{F} 1$ & F2 & F3 \\
\hline Proteins $\%(w / w)$ & $4.40 \pm 0.30^{\mathrm{a}}$ & $3.88 \pm 0.12^{\mathrm{b}, \mathrm{c}}$ & $4.19 \pm 0.05^{\mathrm{a}, \mathrm{c}}$ & $3.77 \pm 0.05^{\mathrm{c}}$ \\
\hline Lipids \% (w/w) & $3.90 \pm 0.05^{\mathrm{b}}$ & $3.10 \pm 0.35^{\mathrm{c}}$ & $4.22 \pm 0.06^{\mathrm{a}, \mathrm{b}}$ & $4.57 \pm 0.06^{\mathrm{a}}$ \\
\hline Carbohydrates \% (w/w) & $18.16 \pm 0.20^{\mathrm{d}}$ & $21.32 \pm 0.00^{c}$ & $21.80 \pm 0.06^{\mathrm{b}}$ & $22.32 \pm 0.03^{\mathrm{a}}$ \\
\hline Total solids \% (w/w) & $27.58 \pm 0.16^{\mathrm{c}}$ & $29.4 \pm 0.43^{\mathrm{b}}$ & $31.15 \pm 0.17^{\mathrm{a}}$ & $31.68 \pm 0.15^{\mathrm{a}}$ \\
\hline $\mathrm{pH}$ & $4.47 \pm 0.00^{\mathrm{a}}$ & $4.45 \pm 0.00^{\mathrm{b}}$ & $4.44 \pm 0.00^{\mathrm{c}}$ & $4.42 \pm 0.00^{\mathrm{d}}$ \\
\hline Titratable acidity & $0.92 \pm 0.01^{\mathrm{b}}$ & $0.93 \pm 0.01^{b}$ & $0.99 \pm 0.01^{\mathrm{a}}$ & $1.00 \pm 0.03^{\mathrm{a}}$ \\
\hline Overrun $\%(w / w)$ & $11.8 \pm 0.3^{c}$ & $12.9 \pm 0.8^{\mathrm{c}}$ & $14.8 \pm 0.7^{b}$ & $18.2 \pm 0.2^{\mathrm{a}}$ \\
\hline Hardness $\left(\mathrm{g}^{-1}\right)$ & $16680^{\mathrm{a}}$ & $17319.5^{\mathrm{a}}$ & $16583^{\mathrm{a}}$ & $14053^{\mathrm{a}}$ \\
\hline
\end{tabular}

All measurements were expressed as means $\pm \mathrm{SD}(\mathrm{n}=3)$.

Different superscript letters in the same line indicate significant differences in Tukey's test $(\mathrm{P}<0.05)$.

Air is a fundamental element in ice cream composition. Its expansion, measured through overrun, consists of one of the most important technical parameters in frozen desserts production (MUSE \& HARTEL, 2004). Overrun affects physical characteristics of ice cream such as texture, melting rate, and sensory properties, in addition to product price (REZAEI et al., 2014; SKRYPLONEK et al., 2019). The formulations obtained overruns between $11.8-18.2 \%(\mathrm{w} / \mathrm{w})$. Also, the overrun increased significantly in samples F2 and F3 regarding the control sample $(\mathrm{F} 0)(\mathrm{P}<0.05)$ (Table 2). Similar results were demonstrated by REZAEI et al. (2014) in frozen yogurts containing inulin. In contrast, TIWARI et al. (2015) observed nonsignificant variations in overrun values of low-fat ice cream added to different levels of inulin. Likewise, SKRYPLONEK et al. (2019), who investigated the effect of adding $\kappa$-carrageenan and corn starch in lactose-free frozen yogurts, did not observe the influence of the stabilizers studied on overrun.

In this context, the $\mathrm{pH}$ also plays a central role in the variation of overrun. According to LAJNAF et al. (2018), the foam formation and stability are more pronounced in acid whey - the type of whey used in the present study -, due to the reduction of the electrostatic repulsion of the $\alpha$-lactalbumin and $\beta$-lactoglobulin proteins when the $\mathrm{pH}$ is close to the proteins isoelectric point $(\mathrm{pI} \alpha-\mathrm{La}=4.1-4.8 ; \mathrm{pI} \beta-\mathrm{Lg}=$ 5.2). In our studies, the formulations showed a $\mathrm{pH}$ of $4.42-4.47$, resting in the isoelectric point zone of the proteins involved with this behavior. The formulation F3 presented the lowest $\mathrm{pH}$ value (Table 2 ) associated with the highest overrun, displaying statistical difference to the other treatments $(\mathrm{P}<0.05)$. Those authors also point out that the interfacial properties of acid whey are preserved at the air-water interface, even after a heat treatment at $90{ }^{\circ} \mathrm{C}$ of the whey, as occurred in the present study. This factor favors the maintenance of air bubbles trapped in food matrices such as frozen yogurts. Also, LAZIDIS et al. (2016) related $\beta$-lactoglobulin and $\alpha$-lactalbumin proteins to gelling and foaming properties, increasing the air retention of various products mixture, including frozen yogurts. Therefore, a synergistic effect between $\beta$-lactoglobulin and $\alpha$-lactalbumin proteins from LCW and inulin contributed to elevating the formulations overrun.

The characteristics of the products depend on the composition of the raw material and processing conditions. Thereby, the nutritional composition, texture, melting behavior, and sensory attributes of ice cream can be influenced by the use of dairy whey (SKRYPLONEK et al., 2019; MENESES et al., 2020). Furthermore, there is a lack of data regarding the use of LCW as a total or partial milk substitute in dairy products, which is a substantial challenge for the industry. Thus, the LCW represents a prominent matrix for fermented dairy products, such as frozen yogurts.

\section{Melting rate}

Figure 1 shows the melting profile of frozen yogurt samples. The formulation F3 obtained the slowest melting between the samples. However, there was no significant effect of inulin addition between the groups studied as compared to control

Ciência Rural, v.51, n.12, 2021. 


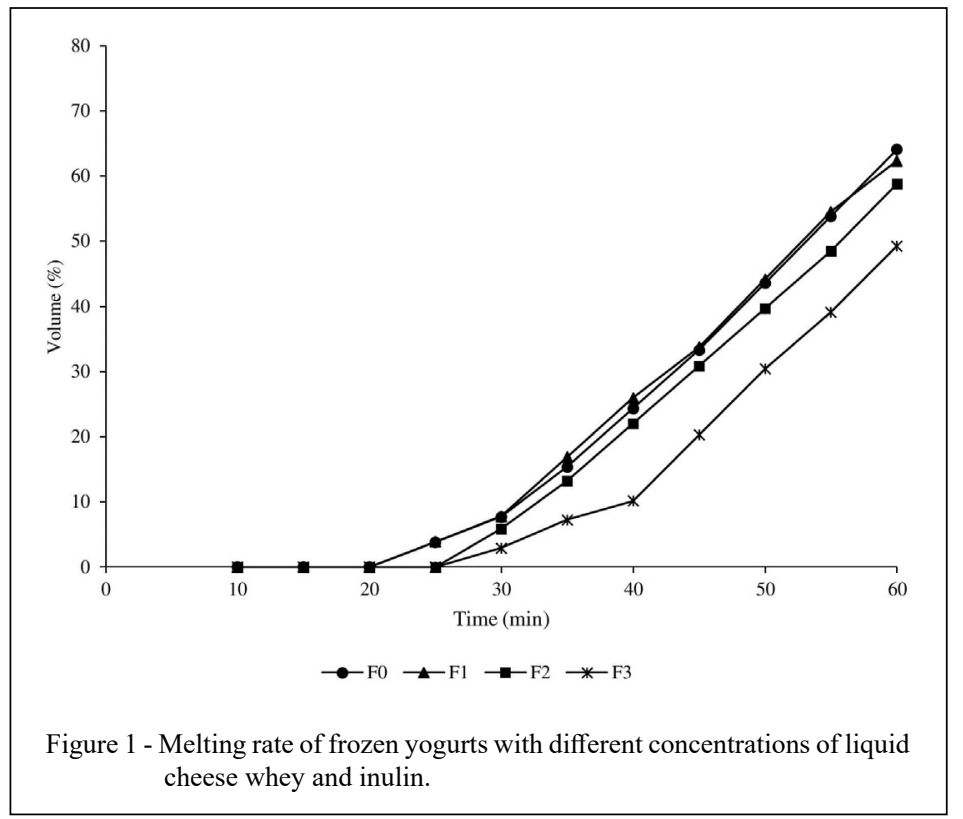

frozen yogurt $(\mathrm{P}<0.05)$. A similar trend was observed by AKBARI et al. (2016), who studied the effects of this dietary fiber on low-fat ice creams.

MUZAMMIL et al. (2017) suggested that inulin may delay the melting of ice creams, due to its high molecular weight, acting as a stabilizing agent and forming a viscous network. Yet, SKRYPLONEK et al. (2019) claimed that production conditions are the main factors to a range of the overrun.

Overrun can also influence the melting rate because the air acts as a thermal insulator and reduces the heat-transfer rate, prolonging the melting time (REZAEI et al., 2014). In the current study, the formulations with higher percentages of overrun obtained slower melt rates, particularly the frozen yogurt F3 (Table 2, Figure 1). Additionally, other studies suggested that whey and inulin confer positive effects to form an internal network matrix and increasing of the air incorporation in ice cream and improving their melting conditions (AKIN et al., 2007; TSUCHIYA et al., 2017).

\section{Texture analysis}

The hardness of frozen yogurt samples ranged between 14053-17319,5 $\mathrm{g}^{-1}$ (Table 2). The formulation $\mathrm{F} 3$ reached the lowest value for hardness. However, there was no statistically significant difference in inulin-containing frozen yogurts as compared to the control group $(\mathrm{P}<0.05)$.
Whey proteins and inulin can develop a synergistic effect in the formation of a gel structure. In this interaction, the gel structure corresponds to a three-dimensional network of bonded polysaccharides, such as inulin and $\beta$-lactoglobulin, resulting in complex coacervates (WALSH et al., 2010). Moreover, the gelling functionality of $\beta$-lactoglobulin occurs when the $\mathrm{pH}$ of the medium is close to its isoelectric point. At this point, these aggregates contain more immobilized water, which may be responsible for increasing the hardness in products containing whey proteins (LAZIDIS et al., 2016).

However, our findings are supported by observations of MOGHADAM et al. (2019), who stated that in concentrations lower than $5 \%(\mathrm{w} / \mathrm{v})$, inulin promotes no expressive modifications in the gel structure of yogurts - base matrix in the elaboration of frozen yogurts.

\section{pH and titratable acidity during storage period}

The results showed that the mean initial $\mathrm{pH}$ of the frozen yogurt $\mathrm{F} 0$ was higher than those of inulin-containing formulations $(\mathrm{P}<0.05)$ (Table 2). Our findings are consistent with those observed by MENESES et al. (2020), who attributed the variation detected to the type and level of LCW added. Yet, the frozen yogurt samples with the highest inulin content (F2 and F3) had mean initial values of titratable acidity significantly higher than the other formulations (F0 
and F1) $(\mathrm{P}<0.05)$. AKIN et al. (2007) and BOENI $\&$ POURAHMAD (2012) reported that the increase of inulin content in fermented milk stimulated the metabolic activity of starter cultures and improved the development of acidity in ice creams and yogurts, respectively.

Figure 2 presents the variations in the values of $\mathrm{pH}$ and titratable acidity in the frozen yogurt formulations during the 120 days of storage at $-18{ }^{\circ} \mathrm{C}$. The results show a decrease in the $\mathrm{pH}$ values and an increase in titratable acidity of all samples, during the first 30 storage days. However, from the sixtieth day of storage, the frozen yogurt formulations had an increase of $\mathrm{pH}$ and a decrease of titratable acidity values. This pattern appears to be associated with a sharp decline from day 60 of storage in starter culture counts ( $S$. thermophilus and L. bulgaricus) (Figure 3A and B).

\section{Enumeration of starter culture microorganisms during storage period}

The variations in the starter cultures counts in the frozen yogurt formulations over the storage period are presented in figure 3 (A and B). There was a slight, but significant, decrease in the viable cell count in both cultures, particularly in the frozen yogurt F0 during freezing for 120 days $(\mathrm{P}<0.05)$. Then again, the formulation F3 present the highest viable cell count in both cultures for 120 days of storage $(\mathrm{P}<0.05)$.

For REZAEI et al. (2014), the maintenance of cellular viability, as observed in the present study, is related to the product composition. Usually, these desserts contain casein, sucrose, and lactose, ingredients that provide cryoprotective properties to the final product. Additionally, AKALIN et al. (2007) indicated that the buffering effect, attributed to the proteins present in the whey, may develop protection on starters and probiotic bacteria in yogurts. This protective effect also is attributed to inulin on traditional yogurt cultures and frozen yogurts (ISIK et al., 2011; MOGHADAM et al., 2019). In this way, these factors may have supported the behavior verified by this research.

A sharp decline from day 60 of storage was observed, especially in the counts of $L$.

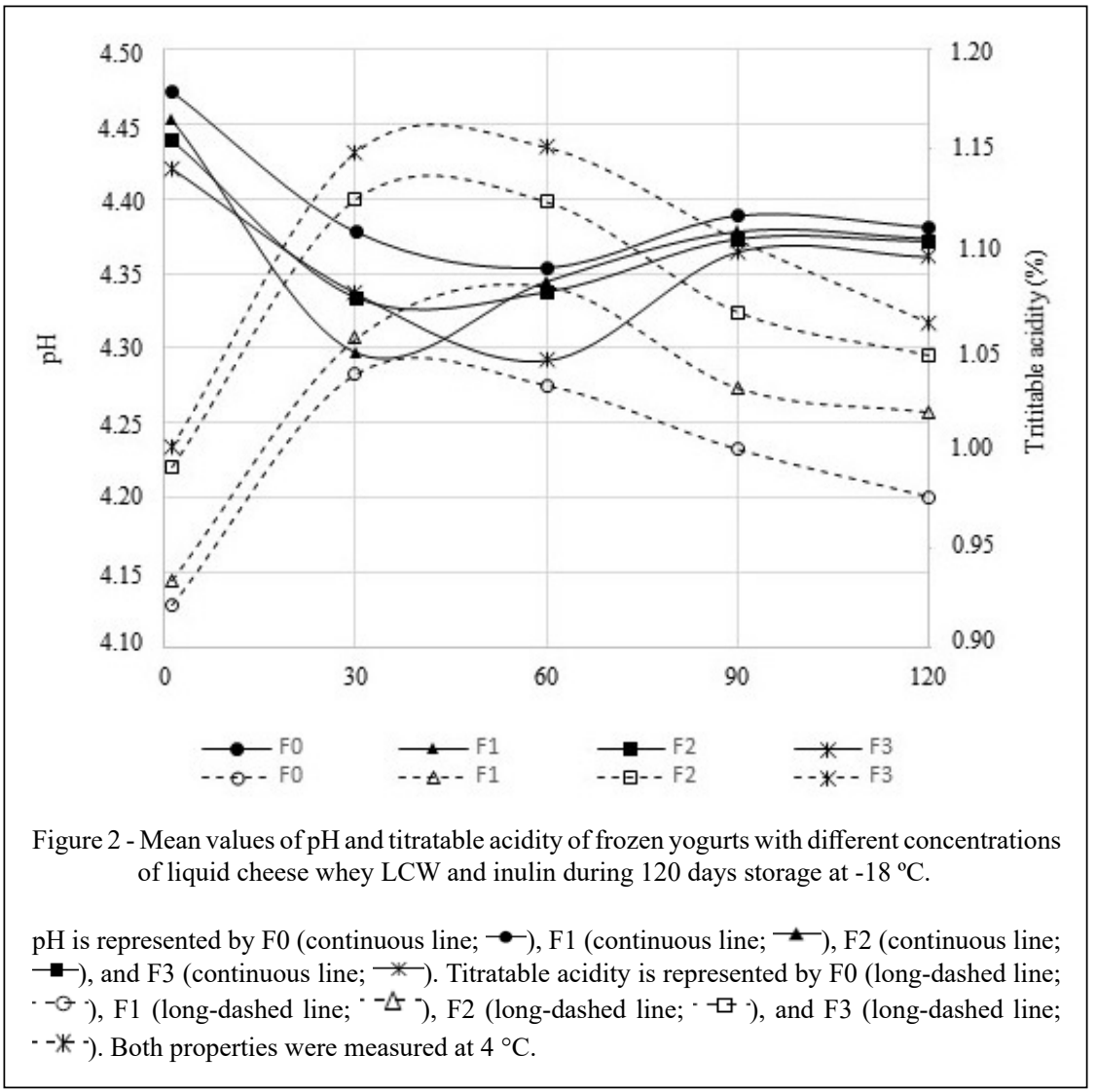

Ciência Rural, v.51, n.12, 2021. 




bulgaricus (Figure 3B). In addition, the frozen yogurt formulations had counts reduced by $1.12 ; 0.85 ; 0.62$; $0.65 \log$ cycles for $L$. bulgaricus and $0.12 ; 0.13$; $0.17 ; 0.10 \log$ cycles for $S$. thermophilus. In the study with commercial frozen yogurts, LOPEZ et al. (1998) observed a similar tendency, stating that the genus Streptococcus was more resistant to freezing compared to Lactobacillus, even in a storage time superior than four months.

\section{CONCLUSION}

The study demonstrated the feasibility of elaborate frozen yogurts containing liquid cheese whey in partial substitution of milk and associated with different levels of inulin. This association provided significant improvements to the physicochemical properties of the frozen yogurts, especially the overrun, as well as positively affected the strains' viability during storage.

Thus, LCW represents a prominent matrix for fermented dairy products, such as frozen yogurts. Therefore, this study contributed to expanding the possibilities of LCW application in the food industry, minimizing its environmental impact, and reducing the costs with residue disposal.

\section{ACKNOWLEDGEMENTS}

The authors would like to thank the Coordenação de Aperfeiçoamento de Pessoal de Nível Superior (CAPES), Brasil - Finance Code 1734/2015 and the Pró-Reitoria de

Ciência Rural, v.51, n.12, 2021. 
Pesquisa e Pós-Graduação (PROPESQ/UFPE) - Finance Code 23076.049914/2017-47 for financial support and research grant. Laticínio FACO Ltda for providing the liquid cheese whey, SweetMix (Beneo-Orafti S.A.) for the donation of the inulin and Laboratório de Experimentação e Análise de Alimentos Nonete Barbosa Guerra da Universidade Federal de Pernambuco for the infrastructure availability.

\section{DECLARATION OF CONFLICT OF INTEREST}

The authors declare no conflict of interest. The founding sponsors had no role in the design of the study; in the collection, analyses, or interpretation of data; in the writing of the manuscript, and in the decision to publish the results.

\section{AUTHORS' CONTRIBUTIONS}

All authors contributed equally for the conception and writing of the manuscript. All authors critically revised the manuscript and approved of the final version.

\section{REFERENCES}

AKALIN, A. S., et al. Effects of fructooligosaccharide and whey protein concentrate on the viability of starter culture in reduced-fat probiotic yogurt during storage. Journal of Food Science, v.72, n.7, p.M222-227. 2007. Available from: <https://onlinelibrary.wiley. com/doi/full/10.1111/j.1750-3841.2007.00436.x>. Accessed: Jul. 15, 2019. doi: 10.1111/j.1750-3841.2007.00436.x.

AKBARI, M., et al. The effect of inulin on the physicochemical properties and sensory attributes of low-fat ice cream. International Dairy Journal, v.57, p.52-55. 2016. Available from: <http:// www.sciencedirect.com/science/article/pii/S0958694616300498>. Accessed: May, 12, 2019. doi: 10.1016/j.idairyj.2016.02.040.

AKIN, M., et al. Effects of inulin and sugar levels on the viability of yogurt and probiotic bacteria and the physical and sensory characteristics in probiotic ice cream. Food Chemistry, v.104, n.1, p.93-99. 2007. Available from: <http://www.sciencedirect.com/ science/article/pii/S0308814606008661>. Accessed: May, 12, 2019. doi: 10.1016/j.foodchem.2006.11.030.

AOAC. Official Methods of Analysis, 20th ed. Washington D.C.: AOAC International. 2016.

BOENI, S.; POURAHMAD, R. Use of inulin and probiotic lactobacilli in synbiotic yogurt production. Annals of Biological Research, v.3, p.3486-3491. 2012.

BRASIL. Consulta Pública n. 28, de 01 de junho de 2000. Regulamento Técnico para fixação de identidade e qualidade de gelados comestíveis, preparados, pós para o preparo e bases para gelados comestíveis. Brasília, Brasil: Ministério da Saúde. 2000

BRASIL. Resolução RDC n. 266, de 22 de setembro de 2005. Institue o Regulamento Técnico para fixação de identidade e qualidade de gelados comestíveis e, preparados para gelados comestíveis, pós para o preparo e bases para gelados comestíveis. Diário Oficial [da] República Federativa do Brasil. Brasília, DF, 23/09/2005.
DAVE, R. I.; SHAH, N. P. Evaluation of media for selective enumeration of Streptococcus thermophilus, Lactobacillus delbrueckii ssp. Bulgaricus, Lactobacillus acidophilus and Bifidobacteria. Journal of Dairy Science, v.79, n.9, p.1529-1536. 1996. Available from: <http://www.sciencedirect.com/science/ article/pii/S002203029676513X>. Accessed: Sept. 14, 2019. doi: 10.3168/jds.S0022-0302(96)76513-X.

GIBSON, G. R., et al. Expert consensus document: The International Scientific Association for Probiotics and Prebiotics (ISAPP) consensus statement on the definition and scope of prebiotics. Nature Reviews Gastroenterology \& Hepatology, v.4, n.8, p.491-502, 2017. Available from: $<$ https://www.nature. com/articles/nrgastro.2017.75>. Accessed: Mar. 20, 2021. doi: $10.1038 /$ nrgastro.2017.75.

GUIMARÃES, J. T., et al. Effect of high-intensity ultrasound on the nutritional profile and volatile compounds of a prebiotic soursop whey beverage. Ultrasonics - Sonochemistry, v.55, p.157-164. 2019. Available from: <https://www.sciencedirect. com/science/article/pii/S1350417719300811>. Accessed: Mar. 20, 2021. doi: 10.1016/j.ultsonch.2019.02.025.

IDF. Yogurt: enumeration of characteristic microorganismsColony count technique at $37^{\circ} \mathrm{C}$. (IDF Standard No. 117). Brussels, Belgium: International Dairy Federation. 2003.

ISIK, U., et al. Frozen yogurt with added inulin and isomalt. Journal of Dairy Science, v.94, n.4, p.1647-1656. 2011. Available from: <http:/www.sciencedirect.com/science/article/ pii/S0022030211001317>. Accessed: Aug. 10, 2020. doi: 10.3168/ jds.2010-3280.

LAJNAF, R., et al. The foaming properties of camel and bovine whey: the impact of $\mathrm{pH}$ and heat treatment. Food Chemistry, v.240, p.295-303. 2018. Available from: <http://www.sciencedirect.com/ science/article/pii/S0308814617312086>. Accessed: Aug. 14, 2020. doi: 10.1016/j.foodchem.2017.07.064.

LAZIDIS, A., et al. Whey protein fluid gels for the stabilisation of foams. Food Hydrocolloids, v.56, p.209-217. 2016. Available from: <http://www.sciencedirect.com/science/article/ pii/S0268005X15000831>. Accessed: Aug. 14, 2020. doi: 10.1016/j.foodhyd.2015.02.022.

LOPEZ, M. C., et al. Survival of lactic acid bacteria in commercial frozen yogurt. Journal of Food Science, v.63, n.4, p.706-708. 1998. Available from: <https://onlinelibrary.wiley.com/doi/ epdf/10.1111/j.1365-2621.1998.tb15818.x>. Accessed: May, 21, 2020. doi: 10.1111/j.1365-2621.1998.tb15818.x.

MANN, B., et al. Bioactive peptides from whey proteins. In Deeth, H. C., \& Bansal, N. (Eds.), Whey proteins: from milk to medicine, p.5195-47. 2019. London: Academic Press. Available from: $<$ http:// dx.doi.org/10.1016/B978-0-12-8121245.00015-1>. Accessed: Mar. 27, 2020. doi: 10.1016/B978-0-12-8121245.00015-1.

MENESES, R. B., et al. Effect of dairy by-products as milk replacers on quality attributes of ice cream. Journal of Dairy Science, v.103, p.0022-10035. 2020. Available from: <http:// www.sciencedirect.com/science/article/pii/S0022030220306548>. Accessed: Sept. 19, 2020. doi: 10.3168/jds.2020-18330.

MITUNIEWICZ-MAŁEK, A., et al. Probiotic monocultures in fermented goat milk beverages - sensory quality of final product. International Journal of Dairy Technology, v.72, n.2, p.240- 
247. 2019. Available from: <https://onlinelibrary.wiley.com/ doi/10.1111/1471-0307.12576 >. Accessed: Mar. 20, 2020. doi: $10.1111 / 1471-0307.12576$

MOGHADAM, B. E., et al. Inulin addition to yoghurt: Prebiotic activity, health effects and sensory properties. International Journal of Dairy Technology, v.72, n.2, p.183-198. 2019. Available from: <https://onlinelibrary.wiley.com/doi/ epdf/10.1111/1471-0307.12579>. Accessed: Sept. 05, 2020. doi: 10.1111/1471-0307.12579.

MUSE, M.; HARTEL, R. Ice cream structural elements that affect melting rate and hardness. Journal of Dairy Science, v.87, p.110. 2004. Available from: <http://www.sciencedirect.com/science/ article/pii/S0022030204731355>. Accessed: May. 15, 2019. doi: 10.3168/jds.S0022-0302(04)73135-5.

MUZAMMIL, H. S., et al. Effect of inulin and glycerol supplementation on physicochemical properties of probiotic frozen yogurt. Food \& Nutrition Research, v.61, n.1, 1290314. 2017. Available from: $<$ https://doi.org/10.1016/j.foodhyd.2017.11.021>. Accessed: Jul. 15, 2019. doi: 10.1080/16546628.2017.1290314.

REZAEI, R., et al. Effect of inulin on the physicochemical properties, flow behavior and probiotic survival of frozen yogurt. Journal of Food Science and Technology, v.51, n.10, p.2809 2814. 2014. Available from: <https://link.springer.com/article/1 0.1007\%2Fs13197-012-0751-7>. Accessed: Jul. 15, 2019. doi: $10.1007 / \mathrm{s} 13197-012-0751-7$.

SOARES, D. S., et al. Aproveitamento de soro de queijo para produção de iogurte probiótico. Arquivo Brasileiro de
Medicina Veterinária e Zootecnia, v.63, n.4, p.996-1002. 2011. Available from: <https://www.scielo.br/scielo.php?pid=S010209352011000400027\&script $=$ sci_abstract\&tlng=pt $>$. Accessed: Apr. 03, 2019. doi: 10.1590/S0102-09352011000400027.

SKRYPLONEK, K., et al. Characteristics of lactose-free frozen yogurt with $\kappa$-carrageenan and corn starch as stabilizers. Journal of Dairy Science, v.102, n.9, p.7838-7848. 2019. Available from: <http://www.sciencedirect.com/science/article/ pii/S0022030219305600>. Accessed: Aug. 17, 2020. doi: 10.3168/jds.2019-16556.

TSUCHIYA, A. C., et al. Lactose-reduced ice cream enriched with whey powder. Semina: Ciências Agrárias, v.38, n.2, p749-758. 2017. Available from: <http://www.uel.br/revistas/uel/index.php/ semagrarias/article/view/25474>. Accessed: Mar. 13, 2020. doi: 10.5433/1679-0359.2017v38n2p749.

TIWARI, A., et al. The effect of inulin as a fat replacer on the quality of low-fat ice cream. International Journal of Dairy Technology, v.68, p.374-380. 2015. Available from: $<$ https:// onlinelibrary.wiley.com/doi/epdf/10.1111/1471-0307.12176>. Accessed: Jul. 15, 2019. doi: 10.1111/1471-0307.12176.

WALSH, H., et al. (2010). Physico-chemical properties, probiotic survivability, microstructure, and acceptability of a yogurt-like symbiotic oats-based product using pre-polymerized whey protein as a gelation agent. Journal of Food Science, v.75, n.5, p.M327337. 2010. Available from: $<$ https://onlinelibrary.wiley.com/doi/ab s/10.1111/j.1750-3841.2010.01637.x>. Accessed: Nov. 21, 2019. doi: $10.1111 / \mathrm{j} .1750-3841.2010 .01637 . \mathrm{x}$ 